\title{
Natural killer cell populations in Egyptians infected with hepatitis $\mathrm{C}$ virus
}

M. Rafik, ${ }^{2}$ G. Sidhom, ${ }^{2}$ R. Mamdouh, ${ }^{1}$ D. Ellebedy ${ }^{2}$ and M. Mohamed ${ }^{2}$

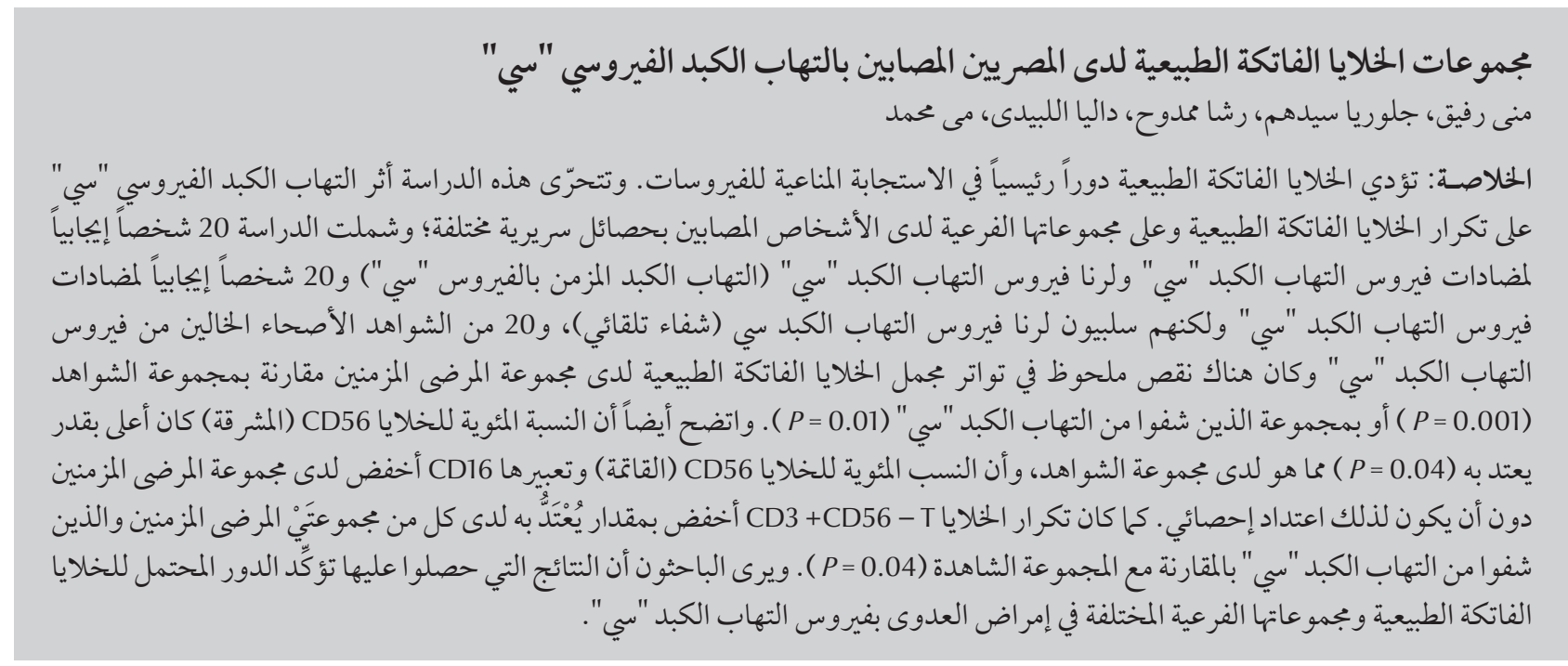

ABSTRACT Natural killer (NK) cells are key players in the immune response to viruses. This study examined the effect of hepatitis $\mathrm{C}$ virus (HCV) on the frequency of NK cells and their subsets in individuals with different clinical outcomes; 20 positive for anti-HCV and HCV-RNA (chronic hepatitis C), 20 positive for anti-HCV but negative for HCV-RNA (spontaneously resolved) and 20 healthy controls free of HCV. There was a significant reduction in the frequency of total NK cells in the chronic group compared to the control $(P=0.001)$ or resolved $(P=0.01)$ groups. The percentage of CD56 (bright) cells was significantly higher than the control group $(P=0.04)$. While the percentages of CD56 (dim) cells and their CD16 expression were lower in the chronic group, this was not statistically significant. The frequency of CD3+CD56- T cells was significantly lower in both the chronic and resolved groups compared to the control group $(P=0.04)$. Our results confirm a potential role of NK cells and the different subsets in the pathogenesis of chronic HCV infection.

\section{Populations de cellules tueuses naturelles chez des Égyptiens infectés par le virus de l'hépatite C}

RÉSUMÉ Les cellules tueuses naturelles jouent un rôle majeur dans la réponse immunitaire aux virus. La présente étude a examiné l'effet du virus de l'hépatite C (VHC) sur la fréquence des cellules tueuses naturelles et de leurs sousgroupes chez des personnes présentant des issues cliniques différentes : 20 patients positifs pour les anticorps antiVHC et pour son ARN (hépatite C chronique) ; 20 personnes positives pour les anticorps anti-VHC mais négatives pour son ARN (résolution spontanée) ; et 20 témoins en bonne santé ne présentant pas d'infection par le virus de I'hépatite C. Une réduction importante de la fréquence des cellules tueuses naturelles totales dans le groupe des patients porteurs d'une infection chronique a été observée par rapport au groupe des témoins $(P=0,001)$ ou au groupe des patients dont l'infection a connu une résolution spontanée $(P=0,01)$. Le pourcentage des cellules CD56 (bright) était significativement supérieur $(P=0,04)$ à celui du groupe témoin. Si le pourcentage des cellules CD56 (dim) et de leur expression de CD16 était inférieur dans le groupe de patients infectés chroniquement, la différence n'était pas statistiquement significative. La fréquence des cellules T CD3+CD56 était très inférieure à la fois dans le groupe de patients infectés chroniquement et dans le groupe ayant bénéficié d'une résolution spontanée par rapport au groupe témoin $(P=0,04)$. Nos résultats confirment le rôle potentiel des cellules tueuses naturelles et de ses différents sous-groupes dans la pathogénèse de l'infection chronique par le virus de l'hépatite C. 


\section{Introduction}

Hepatitis $\mathrm{C}$ virus (HCV) infection has the ability to establish chronic infection in approximately $75 \%-80 \%$ of cases [1-4]. The elimination or persistence of the infection depends on a balance between the immune response and the virus replication rate $[5]$ and play a crucial role in the pathogenesis of chronic hepatitis C [6].

Natural killer (NK) cells are potent antiviral cells which eliminate the virus through direct killing and cytokine production, and are the key players in immune responses to viruses [7]. Like many other viruses, HCV has evolved strategies to evade detection and elimination by NK cells and these have been proposed as a mechanism of virus persistence and chronic infection [8].

According to CD56 expression, NK cells are divided into 2 subsets, dim and bright [9]. Dim NK cells are mainly cytolytic and comprise more than $90 \%$ of NK cells in peripheral blood, whereas bright NK cells are immune-regulatory mainly through cytokine production, and display homing receptors required for migration to 2ry lymph nodes $[10,11]$.

CD56 together with natural $\mathrm{T}$ (NT) cells comprise about $5 \%-15 \%$ of the peripheral $\mathrm{T}$ cell pool and up to $50 \%$ of $\mathrm{T}$ cells within the liver microenvironment, which is the primary site of $\mathrm{HCV}$ replication [12]. These cells have been reported to be impaired in the blood and/or liver of chronic HCV patients [12-16].

$\mathrm{HCV}$ may evade the immune response either by inhibition of NK cell activation receptor genes or by decreasing the activity of these cells by reducing their number and function in chronically infected individuals $[17,18]$. Also, the inheritance of particular inhibitory killer immunoglobulin-like receptors genes, which control NK cell activity, may play a role in predisposing to chronicity [19].
Recently, altered NK cell frequency has been suggested to contribute to the impaired cellular immune response and virus persistence [8]. Some T cells are known to express NK cells receptors (NKRs) and mediate functions of both $\mathrm{T}$ cells and NK cells [13]. Studies suggest that $\mathrm{HCV}$ inhibits receptor genes in the activation of NK cells [20], and the phenotypes and/or functional activities of various populations of $\mathrm{NKR}+\mathrm{T}$ cells have been reported to be impaired in chronic hepatitis $C$ patients $[16,21]$.

In order to study the possible role that NK cells might play in the pathogenesis of the different clinical outcomes of HCV infection in our population, we aimed in this study to assess the impact of HCV on the frequency and subset distribution of circulating NK cells, including CD56 dim and bright populations and CD56 + NT cells in different clinical outcomes of HCV infection.

\section{Methods}

\section{Participants}

The study included 60 participants: 40 health care workers (HCWs), who were a part of a screening programme for HCV infection among HCWs at the internal medicine hospital of AinShams University, and 20 age- and sexmatched healthy volunteers recruited from the same hospital, who were negative for both HCV antibody and HCV RNA, who served as a control group. Exclusion criteria for all groups included interferon or ribavirin therapy and dialysis. Written informed consent was obtained from all the participants and the study was approved by the ethical committee of the National Research Centre in Cairo, Egypt.

\section{Methodology}

All participants were screened for HCV antibodies (HCV-Ab) by a 3rd generation enzyme-linked immunosorbent assay (Diasorin SPA, Italy) and HCV-RNA by qualitative real-time polymerase chain reaction (Stratagene $\mathrm{Mx} 3000 \mathrm{P}$ ). The percentage of total circulating NK cells, NK subsets (including both CD56 dim and bright, with their CD16 expression), total $\mathrm{T}$ cells and CD56+NT cells was characterized by flow cytometry using anti CD3, CD56 and CD16 monoclonal antibodies.

For flow cytometric analysis, $3 \mathrm{~mL}$ whole blood were withdrawn from each participant on ethylenediaminetetraacetic acid (EDTA), and layered over Ficoll-Hypaque (density 1.077 $\mathrm{g} / \mathrm{L}$ ) (Amersham Biosciences) and centrifuged at $2000 \times \mathrm{g}$ for $20 \mathrm{~min}$ at $24^{\circ} \mathrm{C}$. The mononuclear layer was carefully separated, washed 3 times with phosphate buffer saline (PBS), and the cell pellet was resuspended in $1 \mathrm{~mL}$ FACS buffer $(500 \mathrm{~mL}$ PBS $+5 \mathrm{~mL}$ pooled human serum $+5 \mathrm{~mL}$ fetal bovine serum $+1 \mathrm{~mL}$ sodium azide). Then, the mononuclear layer was stained with CD16-FITC, CD56-PE and CD3-PECy5 monoclonal antibodies (Sigma), according to the manufacturer's instructions. Briefly, $5 \mu \mathrm{L}$ of each monoclonal antibody were added to $100 \mu \mathrm{L}$ of the resuspended cells and incubated for 20 min at $4{ }^{\circ} \mathrm{C}$ in the dark. Then $1 \mathrm{~mL}$ of FACS buffer was added followed by centrifugation for $5 \mathrm{~min}$ at $1500 \times \mathrm{g}$. Finally, $500 \mu \mathrm{L}$ of supernatant were discarded and samples were ready for processing on the flow cytometer.

Flow cytometric analysis was done using the EPICS-XL Coulter (Coulter Diagnostics, Hialeah, Florida, United States of America), with standard filter setting using $488 \mathrm{~nm}$ wavelength laser excitation. The following parameters were used: linear forward scatter, side scatter $(\log ), \log$ fluorescence 1 for detection of CD 16-FITC, log fluorescence 2 for detection of CD56-PE and $\log$ fluorescence 4 for CD3-PE-Cy5.

\section{Statistical analysis}

Data were analysed using SPSS, version 15.0. Qualitative data are presented as frequency and percentage, while 
quantitative data are presented as mean, standard deviation (SD) and range. The chi-squared test was used to compare qualitative variables, and the Student $t$-test was used to compare quantitative variables. A $P$-value $<0.05$ was considered statistically significant; $P<0.01$ was considered highly significant.

\section{Results}

According to their HCV-Abs and HCV-RNA results, our patients were divided into a "spontaneously resolved patient group" which included $20 \mathrm{pa}-$ tients who were positive for anti-HCV and negative for HCV-RNA, and a "chronic hepatitis C patient group" included 20 patients who were positive for both anti-HCV and HCV-RNA. The mean percentage of the cell populations in the different groups are shown and compared in Table 1.

On comparing the percentage of different cell populations in the different groups, the percentage of the total circulating NK cell population was significantly lower in chronic hepatitis C patients [mean 3.3 (SD 1.9)] compared to either the spontaneously resolved group $[9.3($ SD 6.3) $](P=0.01)$ or the healthy control group [9.5 (SD 4.5)] $(P=0.001)$ (Table 1).
As regards NK subsets, the CD56 (bright) NK cell population was significantly higher in chronic hepatitis C patients than in the healthy control group [mean 12.2 (SD 7.1) vs 5.9 (SD 5.5), $P=0.04]$. In the spontaneously resolved group the CD56 (bright) NK cell population was also higher but this was not statistically significant [mean 12.2 (SD 7.1) vs 10.6 (SD 9.40), $P=$ 0.4]. Although the percentage of CD56 (dim) NK cells was lower in chronic hepatitis $C$ patients than in the control group, this was not was statistically significant $(P=0.05)$ (Table 1). CD 16 expression was lower on CD56 (dim) NK cells of chronic hepatitis $C$ patients than healthy controls or spontaneously resolved patients but not significantly so ( $P=0.13$ and $P=0.2$ respectively).

The percentage of non-CD56 expressing $\mathrm{T}$ cells (CD3+CD56-T) was significantly lower in both chronic hepatitis $\mathrm{C}$ patients and spontaneously resolved patients compared to healthy controls $(P=0.04)$. The percentage of CD56+NT cells showed no statistically significant difference between the different groups.

\section{Discussion}

In our study, we examined the frequency of circulating NK cell populations (total and subsets) as well as total $\mathrm{T}$ cells and CD56+NT cells in peripheral blood of both chronic hepatitis $\mathrm{C}$ patients and spontaneous resolvers compared to a control group of healthy volunteers using flow cytometry.

Our results revealed that the total circulating NK cells were highly significantly different in the different studied groups. A significant reduction in the frequency of circulating total NK cells in chronic hepatitis $\mathrm{C}$ patients compared to either healthy controls or spontaneous resolvers was found. Total NK cell frequency and/or cytotoxic activity have been reported to be low in chronically infected patients in several studies $[8,22]$.

As regards NK cell subsets, the percentage of CD56 (bright) NK cells was significantly higher in chronic hepatitis $C$ patients than in the resolved or control groups, while the percentage of CD56(dim) NK cells was lower in chronic hepatitis $\mathrm{C}$ patients than in the other groups. This concurs with several studies [8,16,23,24]; Morishima et al. found that the percentage of CD56(dim) cytolytic NK cells was $30 \%$ lower in HCV-infected patients compared with uninfected subjects and this was paralleled by a decrease in circulating NK cells [16]. Meier et al. suggested that the deficit in interleukin 15 (IL-15) might be responsible for

\begin{tabular}{|c|c|c|c|c|c|c|}
\hline \multirow[t]{2}{*}{ Cell population } & Controls & $\begin{array}{c}\text { Chronic } \\
\text { hepatitis } C^{a}\end{array}$ & $\begin{array}{l}\text { Spontaneously } \\
\text { resolved }^{\mathrm{b}}\end{array}$ & \multirow[t]{2}{*}{$\begin{array}{l}P \text {-value (control } \\
\text { vs chronic) }\end{array}$} & \multirow[t]{2}{*}{$\begin{array}{l}P \text {-value (control vs } \\
\text { resolved) }\end{array}$} & \multirow[t]{2}{*}{$\begin{array}{l}P \text {-value (chronic } \\
\text { vs resolved) }\end{array}$} \\
\hline & Mean (SD) & Mean (SD) & Mean (SD) & & & \\
\hline Total T cells & $64.1(10.4)$ & $50.2(16.9)$ & $58.6(10.9)$ & 0.08 & 0.12 & 0.3 \\
\hline CD56+NT & $3.3(1.3)$ & $4.7(4.8)$ & $4.7(3.5)$ & 0.8 & 0.4 & 0.7 \\
\hline CD3+CD56-T & $60.8(10.7)$ & $45.5(15.8)$ & $53.9(12.2)$ & 0.04 & 0.04 & 0.2 \\
\hline Total NK & $9.5(4.5)$ & $3.3(1.9)$ & $9.3(6.3)$ & 0.001 & 0.5 & 0.01 \\
\hline NK(dim) & $94.1(5.5)$ & $87.8(9.6)$ & $89.4(9.4)$ & 0.05 & 0.1 & 0.3 \\
\hline NK(dim) CD16+ & $92.2(6.2)$ & $86.0(8.9)$ & $90.7(6.03)$ & 0.13 & 0.5 & 0.2 \\
\hline NK(bright) & $5.9(5.5)$ & $12.2(7.1)$ & $10.6(9.4)$ & 0.04 & 0.1 & 0.4 \\
\hline NK(bright) CD16+ & $38.9(13.3)$ & $41.1(9.5)$ & $47.9(18.1)$ & 0.6 & 0.14 & 0.5 \\
\hline
\end{tabular}

a Positive for both anti-HCV and HCV-RNA.

${ }^{b}$ Positive for anti-HCV and negative for HCV-RNA.

$S D=$ standard deviation; $N T=$ natural $T$ cells; $N K=$ natural killer cells. 
this change [25]. IL-15 is thought to regulate the function of NK cells and to promote their survival ex vivo [26], and abnormalities in the production of this cytokine contribute to a reduction in NK cell number and a decrease in the CD56(dim) population in $\mathrm{HCV}$ infection.

The frequency of the CD56(dim) $16+$ subset was low in our chronic hepatitis $\mathrm{C}$ patients compared to the resolved or healthy control groups, which is in agreement with Dessouki et al. [8], suggesting the expansion of NK cells is to produce interferon-gamma, while dim cells decrease to minimize cytotoxicity and limit liver damage [27].

In agreement with Corado et al. [28], there was no statistically significant difference in the percentage of total $\mathrm{T}$ cells between the different studied groups. However, the percentage of CD3+CD56- cells was significantly lower in chronic hepatitis $\mathrm{C}$ patients and spontaneous resolvers than in healthy controls. This might be due to a decrease in other $T$ cell populations including $\mathrm{CD} 4+$ and/or CD8+ T cells [29].
Collectively, the results of our study confirm a potential role of NK cells and the different subsets in chronic $\mathrm{HCV}$ infection. More focused research on this cell population with its different stimulatory, costimulatory and inhibitory receptors might answer questions concerning the pathogenesis of chronicity in HCV infection. This knowledge could help in the design of more effective therapeutic approaches for $\mathrm{HCV}$ infection and contribute to the improvement of antiviral therapy and the eradication of the virus.

\section{References}

1. Hepatitis viruses. In: Ryan KJ, Ray CG. Sherris medical microbiology: an introduction to infectious diseases, 4th ed. New York, Mcgraw-Hill, 2004:551.

2. Golden-Mason L, Rosen HR. Natural killer cells: primary target for hepatitis C virus immune evasion strategies? Liver Transplantation, 2006, 12:363-372.

3. Alter MJ. Epidemiology of hepatitis C virus infection. World Journal of Gastroenterology, 2007, 13:2436-2441.

4. Bowen DG, Walker CM. Adaptive immune responses in acute and chronic hepatitis C virus infection. Nature, 2005, 436:946-952.

5. Pawlotsky JM. Pathophysiology of hepatitis C virus infection and related liver disease. Trends in Microbiology, 2004, 12:96-102.

6. Hiroishi K, Ito T, Imawari M. Immune responses in hepatitis $C$ virus infection and mechanisms of hepatitis $C$ virus persistence. Journal of Gastroenterology and Hepatology, 2008, 23:1473-1482.

7. Lanier LL. NK cell recognition. Annual Review of Immunology, 2005, 23:225-274.

8. Dessouki $\mathrm{O}$ et al. Chronic hepatitis $\mathrm{C}$ viral infection reduces NK cell frequency and suppresses cytokine secretion: Reversion by anti-viral treatment. Biochemical and Biophysical Research Communications, 2010, 393:331-337.

9. Caligiuri MA. Human natural killer cells. Blood, 2008, 112:461469.

10. Cooper MA, Fehniger TA, Turner SC. Human natural killer cells: A unique innate immunoregulatory role for the CD56 (bright) subset. Blood, 2001, 97:3146-3151.

11. Campbell JJ, Qin S, Unutmaz D. Unique subpopulations of CD56 ${ }^{+}$NK and NK-T peripheral blood lymphocytes identified by chemokine receptor expression repertoire. Journal of Immunology (Baltimore, MD: 1950), 2001, 166:6477-6482.

12. Doherty DG, O'Farrelly C. Innate and adaptive lymphoid cells in the human liver. Immunological Reviews, 2000, 174:5-20.

13. McMahon CW, Raulet DH. Expression and function of NK cell receptors in $\mathrm{CD}^{+} \mathrm{T}$ cells. Current Opinion in Immunology, 2001, 13:465-470.

14. Deignan $\mathrm{T}$ et al. Decrease in hepatic CD56+ T cells and Va24+ natural killer T cells in chronic hepatitis C viral infection. Journal of Hepatology, 2002, 37:101-108.
15. Lucas $\mathrm{M}$ et al. Frequency and phenotype of circulating doublepositive natural killer T cells during hepatitis $\mathrm{C}$ virus infection. Journal of Virology, 2003, 77:2251-2257.

16. Morishima C et al. Decreased NK cell frequency in chronic hepatitis $\mathrm{C}$ does not affect ex vivo cytolytic killing. Hepatology (Baltimore, Md.), 2006, 43:573-580.

17. Thimme R, Lohmann V, Weber F. A target on the move: innate and adaptive immune escape strategies of hepatitis $C$ virus. Antiviral Research, 2006, 69:129-141.

18. Golden-Mason L, Rosen HR. Natural killer cells: primary target for hepatitis $\mathrm{C}$ virus immune evasion strategies. Liver Transplantation, 2006, 12:363-372.

19. Khakoo SI et al. HLA and NK cell inhibitory receptor genes in resolving hepatitis C virus infection. Science, 2004, 305:872874.

20. Jinushi $M$ et al. Negative regulation of NK cell activities by inhibitory receptor CD94/NKG2A leads to altered NK cellinduced modulation of dendritic cell functions in chronic hepatitis C virus infection. Journal of Immunology (Baltimore, MD: 1950), 2004, 15:6072-6081.

21. Kronenberg M. Toward an understanding of NKT cell biology: progress and paradoxes. Annual Review of Immunology, 2005, 23:877-900.

22. Golden-Mason L et al. Hepatic interleuklin 15 (IL-15) expression: implications for local NK/NKT cell homeostasis and development. Clinical and Experimental Immunology, 2004, 138:94-101.

23. Golden-Mason L et al. Altered natural killer cell subset distributions in resolved and persistent hepatitis $C$ virus infection following single source exposure. Gut, 2008, 57:1121-1128.

24. Lin AW et al. CD56+dim and CD56 bright cell activation and apoptosis in hepatitis $\mathrm{C}$ virus infection. Clinical and Experimental Immunology, 2004, 137:408-416.

25. Meier UC et al. Shared alterations in NK cell frequency, phenotype, and function in chronic human immune-deficiency virus and hepatitis C virus infections. Journal of Virology, 2005, 79:12365-12374.

26. Cooper MA, Fehniger TA, Caligiuri MA. The biology of hue man natural killer-cell subsets. Trends in Immunology, 2001, 22:633-640.

27. Lee $S$ et al. Increased proportion of the CD56(bright) NK cell subset in patients chronically infected with hepatitis $C$ virus 
(HCV) receiving interferon-alpha and ribavirin therapy. Journal of Medical Virology, 2010, 82:568-574.

28. Corado J et al. Impairment of natural killer (NK) cytotoxic activity in hepatitis C virus (HCV) infection. Clinical and Experimental Immunology, 1997, 109:451-457.
29. Chisari FV. Unscrambling hepatitis C virus-host interactions. Nature, 2005, 436:930-932

\section{Prevention and control of viral hepatitis infection: framework for global action}

Around 500000000 people are chronically infected with hepatitis B virus (HBV) or hepatitis C virus (HCV).

Approximately 1000000 people die each year (about $2.7 \%$ of all deaths) from causes related to viral hepatitis, most commonly liver disease, including liver cancer. An estimated 57\% of cases of liver cirrhosis and $78 \%$ of cases of primary liver cancer result from $\mathrm{HBV}$ or $\mathrm{HCV}$ infection.

Despite affecting such a huge number of people worldwide, these diseases remain largely unknown, undiagnosed and untreated. WHO's Prevention and control of viral hepatitis infection: framework for global action describes the 4 areas of work to prevent, treat and save the lives of people infected with hepatitis through targeted regional and country-specific strategies. The 4 strategic axes are: i) Raising awareness, promoting partnerships, and mobilizing resources; ii) Evidencebased policy and data for action; iii) Prevention of transmission; and iv) Screening, care and treatment.

Further information about this document and the Global Hepatitis Programmes is available at: http:/ /www.who.int/ topics/hepatitis/en/ 